\title{
Pengaruh Suplementasi Lisin terhadap Karakteristik Karkas Itik Lokal Jantan Umur Sepuluh Minggu
}

\author{
Bahtiar Nur Khalis Amiruddin $^{1}$, Sudiyono ${ }^{2}$ dan Adi Ratriyanto ${ }^{2}$ \\ ${ }^{1}$ Sarjana Program Studi Peternakan, Fakultas Pertanian Universitas Sebelas Maret \\ ${ }^{2}$ Program Studi Peternakan Fakultas Pertanian,Universitas Sebelas Maret \\ Jl. Ir. Sutami 36A, Surakarta 57126
}

\begin{abstract}
ABSTRAK
Penelitian ini bertujuan untuk mengetahui pengaruh suplementasi lisin dalam pakan terhadap persentase karkas, lemak abdominal dan kadar lemak daging itik lokal jantan umur sepuluh minggu. Penelitian ini menggunakan 80 ekor itik lokal jantan umur dua minggu (bobot rata-rata 326,40 $\pm 31,84$ g/ekor). Rancangan percobaan yang digunakan adalah Rancangan Acak Lengkap (RAL) pola searah dengan empat macam perlakuan, terdiri dari empat ulangan dan setiap ulangan terdiri dari lima ekor itik lokal jantan. Pakan terdiri dari pollard, jagung kuning, bungkil kedelai, minyak sawit, premix dan lisin (dalam bentuk L-Lysine $\mathrm{HCl}$ ). Perlakuan yang diberikan yaitu suplementasi lisin ke dalam pakan sebanyak 0 (kontrol), 0,05, 0,10 dan 0,15\% Peubah yang diamati adalah bobot potong, persentase lemak abdominal, persentase karkas dan kadar lemak daging. Hasil penelitian menunjukkan bahwa suplementasi lisin dalam pakan itik lokal jantan umur sepuluh minggu dapat menurunkan $(\mathrm{P}<0,01)$ kadar lemak abdominal tetapi tidak berpengaruh terhadap bobot potong, persentase karkas dan kadar lemak daging. Kesimpulan yang dapat diambil dari penelitian ini adalah suplementasi lisin sampai taraf 0,15 persen dari total pakan dapat menurunkan persentase lemak abdominal namun tidak mempengaruhi bobot potong, persentase karkas dan kadar lemak daging itik lokal jantan umur sepuluh minggu.
\end{abstract}

Kata kunci: itik lokal, lisin, bobot potong, karkas, lemak abdominal

\section{The Effect of Lysine Supplementation on Carcass Characteristics of Male Local Duck Aged Ten Weeks}

\begin{abstract}
The objective of the study was to determine the effect of lysine supplementation in ration on carcass yield, abdominal fat and fat content of ten-week old male local duck meat. The study

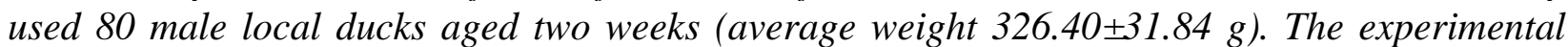
design used was Completely Randomized Design with four treatments, consisted of four replications with five male local ducks each. Rations consisted of pollard, yellow corn, soybean meal, palm oil, premix and lysine (in the form of L-Lysine HCl). The basal diet was supplemented with lysine at the amount of 0 (control), 0.05, 0.10 and 0.15\%. The variables observed were the slaughter weight, abdominal fat percentage, carcass yield and fat content of the meat. The results showed that lysine supplementation in the diet of local duck ten-week old male decreased ( $P$ $<0.01)$ abdominal fat but did not affect slaughter weight, carcass yield and fat content of meat. It can be concluded that lysine supplementation of 0.15 percent of the total ration can reduce abdominal fat percentage of ten-week old male local duck meat.
\end{abstract}

Keywords: local duck, lysine, slaughter weight, abdominal fat, carcass. 


\section{PENDAHULUAN}

Daging itik mempunyai kandungan protein $21,4 \%$, lemak $8,2 \%$, abu $1,2 \%$ dan nilai energi $15.900 \mathrm{KCal} / \mathrm{kg}$. Ternak itik memiliki kemampuan lebih tahan penyakit, dapat dipelihara dengan atau tanpa air serta pertumbuhannya lebih cepat daripada ayam buras (Srigandono, 1997). Namun dewasa ini, masyarakat cenderung untuk mengurangi konsumsi produk-produk hewani. Hal ini disebabkan kandungan lemak dan kolesterol (kolesterolfobia) yang terdapat di dalamnya, sehingga mendorong banyak penelitian untuk mengupayakan suatu produk peternakan (daging) yang rendah lemak dan kolesterol.

Lisin merupakan asam amino esensial yang sangat berguna bagi tubuh. Lisin adalah prekusor untuk biosintesis karnitin, sedangkan karnitin merangsang proses $\beta$-oksidasi dari asam lemak rantai panjang yang terjadi di mitokondria. Penambahan lisin ke dalam pakan diharapkan dapat meningkatkan terbentuknya karnitin, dengan demikian lemak tubuh yang mengalami $\beta$-oksidasi semakin meningkat, sehingga mengakibatkan kadar lemak dan kolesterol daging rendah (Susandari et al., 2004). Menurut Gous dan Morris yang disitasi oleh Susandari et al. (2004) penambahan lisin ke pakan ayam sebanyak $7 \mathrm{~g} / \mathrm{kg}$ pakan, lemak dagingnya berjumlah $190 \mathrm{~g} / \mathrm{kg}$ karkas, bila lisin yang ditambahkan 8,5 $\mathrm{g} / \mathrm{kg}$ pakan maka lemak dagingnya turun menjadi $150 \mathrm{~g} / \mathrm{kg}$ karkas (turun sebesar 21 persen).

Berdasarkan hal di atas maka dilakukan penelitian yang bertujuan untuk mengetahui pengaruh suplementasi lisin dalam pakan terhadap persentase lemak abdominal dan kadar lemak daging pada itik lokal jantan umur sepuluh minggu.

\section{MATERI DAN METODE}

Penelitian in menggunakan itik lokal jantan dari jenis itik Mojosari yang diperoleh dari Desa Krasak, Kecamatan Gatak, Kabupaten Sukoharjo sebanyak 80 ekor, dengan bobot badan rata-rata $326,40 \pm 31,84$ g/ekor. Sebanyak 80 ekor itik tersebut didistribusikan ke dalam 16 petak kandang litter dengan ukuran $1,0 \times 1,0 \times 0,5$ meter. Penelitian ini menggunakan empat macam perlakuan pakan, masing-masing perlakuan, diulang empat kali dan setiap ulangan terdiri dari lima ekor itik. Pakan perlakuan terdiri dari pollard, jagung kuning, bungkil kedelai, minyak sawit, premix dan lisin. Lisin disuplementasikan dalam bentuk L-Lysine $\mathrm{HCl}$ sebanyak 0 (kontrol), 0,05, 0,10 dan 0,15\%. Susunan pakan perlakuan dan kandungan nutrien pakan dapat dilihat pada Tabel 1 dan Tabel 2.

Penelitian dilaksanakan selama delapan minggu dengan pemberian pakan dua kali sehari pada pukul 07.00 WIB dan 15.00 WIB. Pakan perlakuan dan air minum diberikan secara ad libitum. Koleksi semua data dilaksanakan pada akhir penelitian. Variabel yang diamati adalah botot potong pada umur 10 minggu, persentase lemak abdominal, persentase karkas dan kadar lemak daging. Bobot potong diperoleh dengan menimbang itik sebelum dipotong yang telah dipuasakan selama 12 jam, dengan satuan g/ekor (Sudiastra, 2001). Persentase lemak abdominal diperoleh dengan cara membagi bobot lemak abdominal dengan bobot potong kemudian dikalikan 100\% (Widiastuti, 2001). Persentase karkas diperoleh dengan membagi bobot karkas dengan bobot potong kemudian dikalikan 100\% (Abubakar dan Nataamijaya, 1999). Kadar lemak daging diperoleh dengan menggunakan metode ekstraksi soxhlet (Atkinson, 1972), dengan menggunakan sampel daging dada bagian kanan.

Semua data yang diperoleh dalam penelitian ini dianalisis menggunakan analisis variansi berdasarkan Rancangan Acak Lengkap (RAL) pola searah untuk mengetahui adanya pengaruh perlakuan terhadap peubah yang diamati. Apabila analisis variansi menunjukkan hasil yang berbeda nyata, maka dilanjutkan dengan Duncan's Multiple Range Test untuk mengetahui perbedaan antar empat mean perlakuan (Yitnosumarto, 1993). 
Tabel 1. Susunan pakan perlakuan

\begin{tabular}{lrrrr}
\hline \multirow{2}{*}{ Bahan Pakan } & \multicolumn{4}{c}{ Level Lisin (\%) } \\
\cline { 2 - 5 } & 0 & 0,05 & 0,10 & 0,15 \\
\hline Pollard & 42,00 & 42,00 & 42,00 & 42,00 \\
Jagung kuning & 31,00 & 30,93 & 30,86 & 30,79 \\
Bungkil kedelai & 22,50 & 22,50 & 22,50 & 22,50 \\
Minyak sawit & 3,00 & 3,00 & 3,00 & 3,00 \\
Premix & 1,50 & 1,50 & 1,50 & 1,50 \\
L-Lysine $\mathrm{HCl}$ & 0,00 & 0,07 & 0,14 & 0,21 \\
\hline
\end{tabular}

Tabel 2. Kandungan nutrien pakan perlakuan

\begin{tabular}{lrrrr}
\hline \multirow{2}{*}{ Nutrien } & \multicolumn{4}{c}{ Level Lisin (\%) } \\
\cline { 2 - 5 } & \multicolumn{1}{c}{0} & 0,05 & 0,10 & \multicolumn{1}{c}{0,15} \\
\hline Energi metabolis (KCal/kg) & 2941,61 & 2939,27 & 2936,92 & 2934,58 \\
Protein kasar (\%) & 17,55 & 17,55 & 17,54 & 17,53 \\
Serat kasar (\%) & 4,73 & 4,73 & 4,73 & 4,73 \\
Lemak kasar (\%) & 7,49 & 7,48 & 7,47 & 7,47 \\
Kalsium (\%) & 0,85 & 0,85 & 0,85 & 0,85 \\
Fosofor (\%) & 0,57 & 0,57 & 0,57 & 0,57 \\
Lisin (\%) & 0,73 & 0,78 & 0,83 & 0,88 \\
\hline
\end{tabular}

\section{HASIL DAN PEMBAHASAN}

Hasil penelitian menunjukkan bahwa suplementasi lisin 0,05 sampai $0,15 \%$ dapat menurunkan persentase lemak abdominal pada itik umur 10 minggu. Sementara itu, bobot potong, persentase karkas dan kadar lemak daging tidak dipengaruhi oleh suplementasi lisin (Tabel 3).

Suplementasi lisin dalam pakan yang mempunyai kandungan lisin cukup tidak mempengaruhi bobot potong itik lokal jantan umur sepuluh minggu. Penelitian Bintang (2000) menunjukkan suplementasi asam amino sampai level 0,20 persen pada pakan berbasis dedak padi yang defisien lisin dapat menaikkan bobot potong itik manila jantan umur sepuluh minggu. Namun pada penelitian Tarigan (2010) tentang penambahan lisin sampai level 1,60 persen dalam pakan basal pada broiler umur 6 minggu bobot potong menunjukkan hasil yang lebih rendah jika dibandingkan dengan penggunaan pakan komersial. Faktor penting yang mempengaruhi bobot potong bila dilihat dalam pemenuhan asam amino adalah keseimbangan antar asamasam amino dalam pakan. Widodo (2000) menjelaskan bahwa problem yang dihadapi dalam penambahan protein dalam pakan adalah keberadaan asam amino esensial menjadi tidak seimbang.

Suplementasi lisin dalam pakan yang mempunyai kandungan lisin cukup tidak mempengaruhi persentase karkas itik lokal jantan umur sepuluh minggu. Hal ini sesuai dengan penelitian Tarigan (2010) tentang penggunaan asam amino lisin dengan penambahan sampai level 1,60 persen dalam pakan basal tidak mempengaruhi persentase karkas broiler umur 6 minggu. Hasil yang sama juga disimpulkan dari penelitian Hutapea (2003) bahwa penambahan lisin sampai level 0,30 persen dalam pakan tidak mempengaruhi persentase karkas broiler umur 6 minggu. Pengaruh lisin dalam menurunkan lemak abdominal yang merupakan salah satu bagian dari komposisi non karkas tidak memberikan dampak perubahan persentase karkas yang besar, karena nilai yang diberikan dari persentase lemak abdominal cukup kecil (maksimal 0,73 persen dari bobot potong). Menurut Soeparno (1994) besarnya persentase non karkas akan mempengaruhi persentase karkas. 
Tabel 3. Pengaruh suplementasi lisin terhadap bobot potong, persentase karkas, persentase lemak abdominal dan kadar lemak daging itik lokal jantan

\begin{tabular}{lrrrr}
\hline \multirow{2}{*}{ Variabel } & \multicolumn{4}{c}{ Level Lisin (\%) } \\
\cline { 2 - 5 } & 0 & 0,05 & 0,10 & 0,15 \\
\hline Bobot potong (g) & 1325,75 & 1535,25 & 1513,50 & 1409,25 \\
Persentase karkas (\%) & 61,26 & 60,72 & 62,01 & 62,11 \\
Persentase lemak abdominal (\%) & $0,73^{\mathrm{a}}$ & $0,32^{\mathrm{b}}$ & $0,33^{\mathrm{b}}$ & $0,39^{\mathrm{b}}$ \\
Kadar lemak daging (\%) & 4,97 & 4,21 & 4,64 & 4,14 \\
\hline a, b $\quad$ Superksrip yang berbeda pada baris yang sama menunjukkan perbedaan yang sangat nyata \\
(P0,01)
\end{tabular}

Suplementasi lisin dalam pakan sebesar $0,05, \quad 0,10$ dan $0,15 \%$ dapat menurunkan $(\mathrm{P}<0,01)$ persentase lemak abdominal. Hal ini sesuai dengan penelitian Tarigan (2010) tentang penggunaan asam amino lisin dengan penambahan sampai level 1,60 persen dalam ramsum basal dapat menurunkan bobot lemak abdominal broiler umur 6 minggu. Hasil yang sama juga disimpulkan dari penelitian Suryana (2004) penambahan lisin sampai level 0,3 persen dalam pakan yang disubtitusi sagu, dapat menurunkan persentase lemak abdominal broiler umur 5 minggu. Hasil yang berbeda sangat nyata antara kontrol dengan ketiga perlakuan lainnya disebabkan karena fungsi lisin yaitu sebagai prekusor untuk biosintesis karnitin. Karnitin berperan merangsang proses $\beta$-oksidasi dari asam lemak rantai panjang yang terjadi di mitokondria (Susandari et al., 2004). Penambahan lisin ke dalam pakan dapat meningkatkan terbentuknya karnitin, dengan demikian lemak tubuh yang mengalami $\beta$-oksidasi semakin meningkat, sehingga penimbunan lemak tubuh dapat berkurang.

Suplementasi lisin dalam pakan yang mempunyai kandungan lisin cukup tidak mempengaruhi kadar lemak daging itik lokal jantan umur sepuluh minggu. Hal ini sesuai dengan penelitian Maryuni (2003) bahwa penambahan lisin sampai level 0,20 persen dalam pakan yang mengandung lisin dalam jumlah yang cukup (1,10 persen), tidak mempengaruhi kadar lemak daging broiler umur 6 minggu.
Menurut Martoharsono (2000) energi yang dikonsumsi apabila tidak digunakan untuk beraktivitas akan ditimbun sebagai glikogen dalam otot dan hati serta dideposisikan di jaringan adiposa dan ekstrahepatik. Hasil yang berbeda tidak nyata diduga disebabkan karena belum terjadi deposoisi pada lemak intramuscular. Soeparno (1994) menyatakan deposisi lemak pada ternak muda terjadi di sekitar jerohan dan ginjal, dengan peningkatan umur deposisi lemak akan terjadi di antara otot (lemak intermuscular), lapisan kulit (lemak subkutan) dan terakhir di antara serabut otot dalam bentuk marbling yang berupa lemak intramuscular.

\section{KESIMPULAN}

Berdasarkan hasil penelitian ini dapat disimpulkan bahwa suplementasi lisin sebesar $0,05-0,15 \%$ dari dapat menurunkan persentase lemak abdominal namun tidak mempengaruhi bobot potong, persentase karkas dan kadar lemak daging itik lokal jantan umur sepuluh minggu.

\section{DAFTAR PUSTAKA}

Abubakar dan A. G. Nataamijaya, 1999. Persentase Karkas dan Bagian-Bagiannya Dua Galur Ayam Broiler dengan Penambahan Tepung Kunyit (Curcuma domestica Val) dalam Ransum. Buletin Peternakan, Vol. 34: 174-179.

Atkinson, T., V. R. Fowler, G. A. Garton and A. K. Lough, 1972. A Rapid Method for the 
Accurate of Lipid in Animal Tissues. Analyst, Vol. 97: 562-568.

Bintang, I. A. K., 2000. Penambahan Lysin dan Methionin pada Dedak untuk Pakan Entog yang Sedang Tumbuh. Balai Penelitian Ternak Ciawi. Bogor.

Hutapea, P. M. H., 2003. Pengaruh Pemberian Tingkat Energi dan Penambahan Lisin dalam Ransum Menggunakan Ubikayu Fermentasi Terhadap Penampilan Produksi Ayam Pedaging. Tesis Program Pasca Sarjana. Universitas Diponegoro. Semarang.

Martoharsono, S., 2000. Biokimia. Jilid 2. Gadjah Mada University Press. Yogyakarta.

Maryuni, S. S., 2003. Pengaruh Kandungan Lisin dan Energi Metabolis Berbeda dalam Ransum yang Mengandung Ubikayu Fermentasi Terhadap Lemak Ayam Broiler. Tesis Program Pasca Sarjana. Universitas Diponegoro. Semarang.

Soeparno, 1994. Ilmu dan Teknologi Daging. Gadjah Mada University Press. Yogyakarta.

Srigandono, B., 1997. Ilmu Unggas Air. Gadjah Mada University Press. Yogyakarta.

Sudiastra, I. W., 2001. Pengaruh Penambahan Efektif Mikroorganisme dalam Ransum Berprotein Rendah Terhadap Komposisi Fisik Karkas Ayam Jantan Tipe Petelur. Majalah Ilmiah Peternakan, Vol. 4: 84-89.
Suryana, 2004. Nilai Nutritif Sagu (Metroxylon Sp.) dan Pengaruhnya dalam Ransum Ayam Broiler dengan Suplementasi Metionin dan Lisin. Tesis Program Pasca Sarjana. Universitas Gadjah Mada. Yogyakarta.

Susandari, L., C. M. S. Lestari dan H. I. Wahyuni, 2004. Komposisi Lemak Tubuh Kelinci yang Mendapat Pakan Pelet dengan Berbagai Aras Lisin. Seminar Nasional Teknologi Peternakan dan Veteriner Fakultas Peternakan. Universitas Diponegoro. Semarang.

Tarigan, T. N., 2010. Penggunaan Asam Amino Metionin dan Lisin dalam Ramsum Terhadap Karkas Broiler Umur Enam Minggu. Skripsi S1 Fakultas Pertanian. Universitas Sumatera Utara. Medan.

Widiastuti, R., 2001. Pengaruh Penambahan Ampas Tahu Fermentasi dalam Pakan terhadap Karkas dan Perlemakan. Skripsi S1 Fakultas Peternakan. Universitas Gadjah Mada. Yogyakarta.

Widodo, W., 2000. Nutrisi dan Pakan Unggas Konseptual. Buku Ajar Fakultas Peternakan. Universitas Muhammadiah Malang. Malang. Yitnosumarto, S., 1993. Perencanaan Percobaan Analisis dan Interprestasinya. Gramedia Pustaka Utama. Yogyakarta. 